\title{
54. Slow Axoplasmic Transport
}

\section{Its Asymmetry in Two Branches of Bifurcating Axons}

\author{
By Hiroshi MorI, Yoshiaki Komrya, and Masanori Kurokawa \\ Department of Biochemistry, Institute of Brain Research, \\ Tokyo University, Faculty of Medicine, Hongo, Tokyo 113 \\ (Communicated by Yushi Uchimura, M. J. A., November 12, 1977)
}

Recent experiments have shown that the slow phase of axoplasmic transport significantly differs in its rate between two branches of bifurcating axons. ${ }^{6}$ ) When L- $\left[\mathrm{U}-{ }^{14} \mathrm{C}\right]$ leucine is injected into the $L_{5}$ dorsal root ganglion (DRG) of the adult rat, the peak of radioactivity of labelled proteins is found to migrate at the rate of $1.0 \mathrm{~mm}$ /day in the peripheral axon (sciatic nerve), in contrast with the slower rate of $0.4 \mathrm{~mm} /$ day in the central axon (dorsal root). The peak of radioactivity becomes broader and tends to split into two or three subpeaks, suggesting the occurrence of two or more groups of migrating materials with slightly different flow rates. ${ }^{6)}$

Lasek and Hoffman have recently defined, in the rat ventral motor neurones and guinea pig hypoglossal neurones, two subcomponents of slow transport which they designated slow component a (SCa) and slow component b (SCb). ${ }^{8)}$ SCa and SCb differ, not only in their rates of migration and molecular species, but also in their role in regenerating axons. ${ }^{8)}$

We report that, in slow transport in the sensory neurones, there are at least three groups of distinct molecular species that migrate at slightly different rates. It is further shown that the flow rate of each of these three groups differs between the two branches, being faster in the peripheral axons than in the central ones.

Materials and methods. Adult albino rats of Wistar strain weighing $250-300 \mathrm{~g}$ were used. L- $\left.{ }^{35} \mathrm{~S}\right]$ Methionine $(200 \mu \mathrm{Ci}$ in $0.4 \mu \mathrm{l})$ was carefully injected into the $\mathrm{L}_{5}$ ganglion, and at prescribed time intervals, the sciatic nerve, ganglion, dorsal root together with a portion of the spinal cord (hemi-cord) were dissected out, and radioactivities in each of consecutive $3 \mathrm{~mm}$ segments were determined as described previously. ${ }^{1), 6)}$ For fluorographic analyses, two serial $3 \mathrm{~mm}$ segments were ground in a glass-glass homogeniser and further in a teflon-glass homogeniser, in the total volume of $400 \mu \mathrm{l}$ of medium which contained (final concentrations) sodium dodecyl sulphate $(\operatorname{SDS}: 2.3 \%, \mathrm{w} / \mathrm{v}), \beta$-mercaptoethanol $(5 \mathrm{mM})$, glycerol $(10 \%, \mathrm{v} / \mathrm{v})$ and Tris- $\mathrm{HCl}(62.5 \mathrm{mM}), \mathrm{pH} 6.8$, and the sample was heated at $95^{\circ} \mathrm{C}$ 
for 5 minutes. A $30 \mu$-aliquot of respective samples was electrophoresed on an SDS-polyacrylamide slab gel $(10 \%, \mathrm{w} / \mathrm{v} ; 2 \mathrm{~mm}$ thick) according to the method of Laemmli. ${ }^{7)}$ Molecular weight markers used were (with their molecular weights in parentheses) bovine serum albumin (BSA), trimer $(204,000)$, rabbit skeletal muscle myosin $(200,000)$, RNA polymerase from $E$. coli, $\beta^{\prime}$ subunit $(165,000)$ and $\beta$ subunit $(155,000)$, BSA, dimer $(136,000)$, BSA, monomer $(68,000)$, rabbit skeletal muscle actin $(43,000)$, RNA polymerase from $E$. coli, $\alpha$ subunit $(39,000)$ and glyceraldehyde 3-phosphate dehydrogenase $(36,000)$. Fluorography was carried out essentially as described by Bonner and Laskey, ${ }^{2)}$ using the RP Royal X-Omat X-ray film (Eastman Kodak Co.) with or without a brief flashing, ${ }^{9)}$ and with Cronex intensifying screen (Lightning-Plus; Du Pont De Numours \& Co.).

Results and discussion. In place of $\mathrm{L}-\left[\mathrm{U}-{ }^{14} \mathrm{C}\right]$ leucine used in our previous experiments, ${ }^{6)}$ L- $\left[{ }^{35} \mathrm{~S}\right]$ methionine was used in the present study, because the latter, due to its higher specific radioactivity $(1,245 \mathrm{Ci} / \mathrm{mmole})$, enabled a more sensitive detection of labelled proteins in fluorography. Flow profiles of labelled proteins

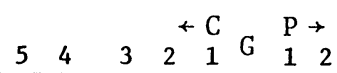

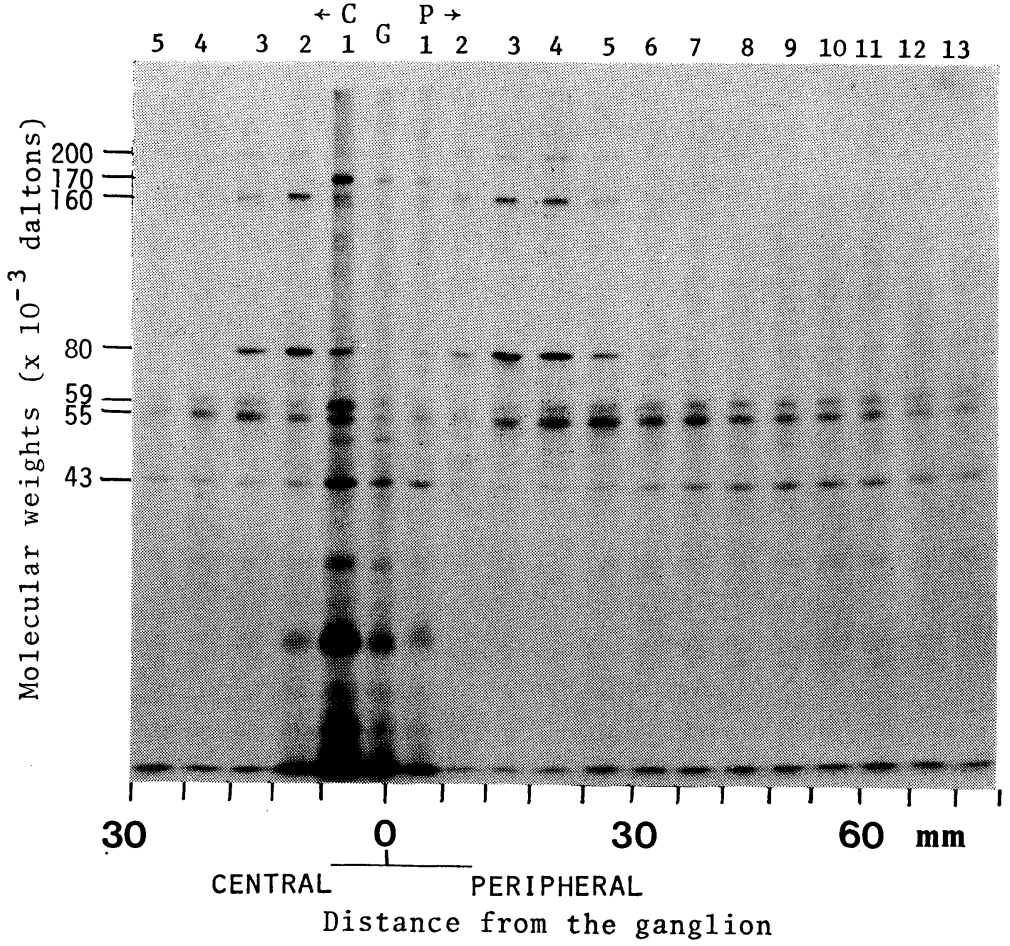

Fig. 1. Fluorograph of axonal peptides 2 weeks after the injection of $\mathrm{L}-\left[{ }^{35} \mathrm{~S}\right]$ methionine into the $\mathrm{L}_{5}$ dorsal root ganglion of the adult rat. 


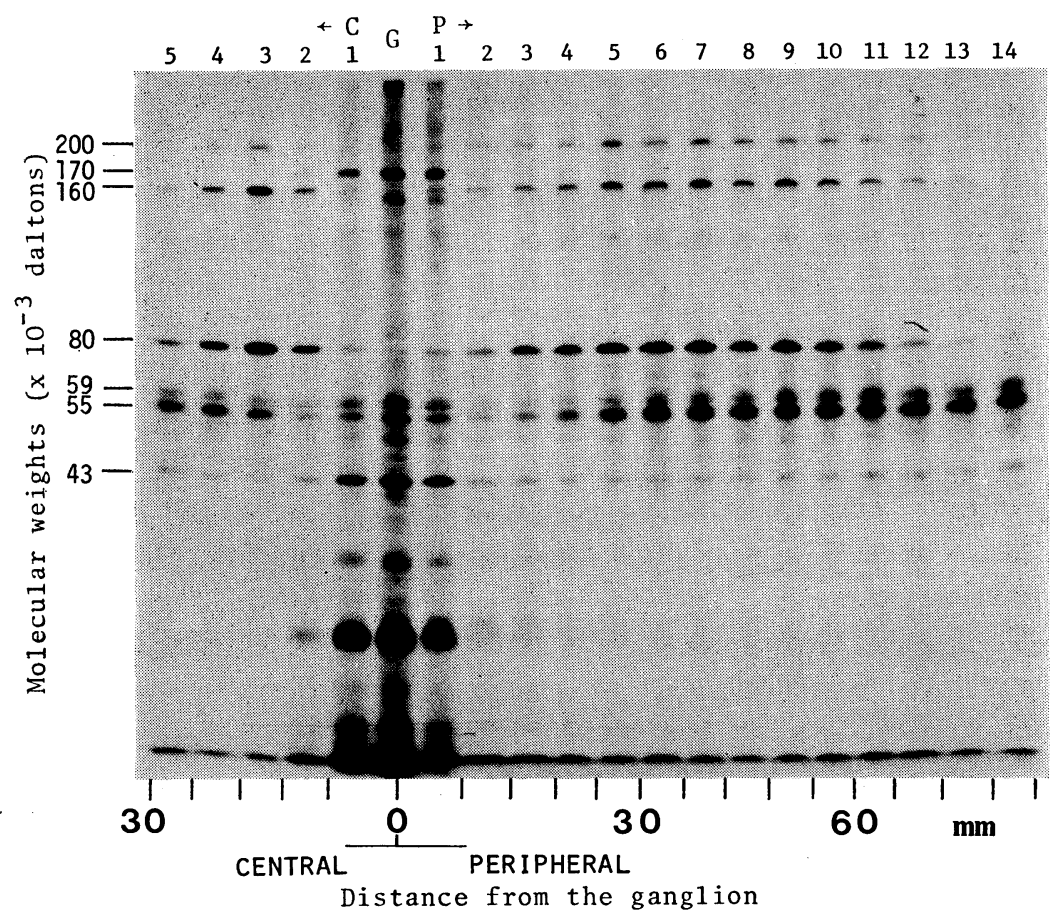

Fig. 2. Fluorograph of axonal peptides 4 weeks after the injection of $\mathrm{L}-\left[{ }^{35} \mathrm{~S}\right]$ methionine into the $\mathrm{L}_{5}$ dorsal root ganglion of the adult rat.

in the central and peripheral branches of DRG cell axons were essentially the same whichever amino acid was used as precursor.

Fluorographs of labelled proteins in consecutive nerve segments 2, 4 and 6 weeks after the isotope injection are shown in Figs. 1, 2 and 3 , respectively. In these figures, electrophoretic banding patterns in the first columns adjacent to the ganglion $\left(P_{1}\right.$ and $\left.C_{1}\right)$ do not necessarily represent the intra-axonal peptides. The ganglion and the $\mathrm{P}_{1}$ and $\mathrm{C}_{1}$ columns are characterised by having a peptide with an apparent molecular weight of 170,000 daltons, which may either be a least-migrating neuronal peptide or a peptide of non-neuronal origin. Among a number of migrating peptides in axons, there are six major ones with apparent molecular weights of 200,000, 160,000, $80,000,59,000,55,000$ and 43,000 daltons, which may be divided into three groups on the basis of their rates of migration within the axon.

Group 1: This consists of 3 peptides with apparent molecular weights of $200,000,160,000$ and 80,000 daltons. Despite minor differences in apparent molecular weights, a striking coincidence of their mutual relative mobilities makes us to consider that the combination of these three peptides is equivalent to the slow-component triplet 


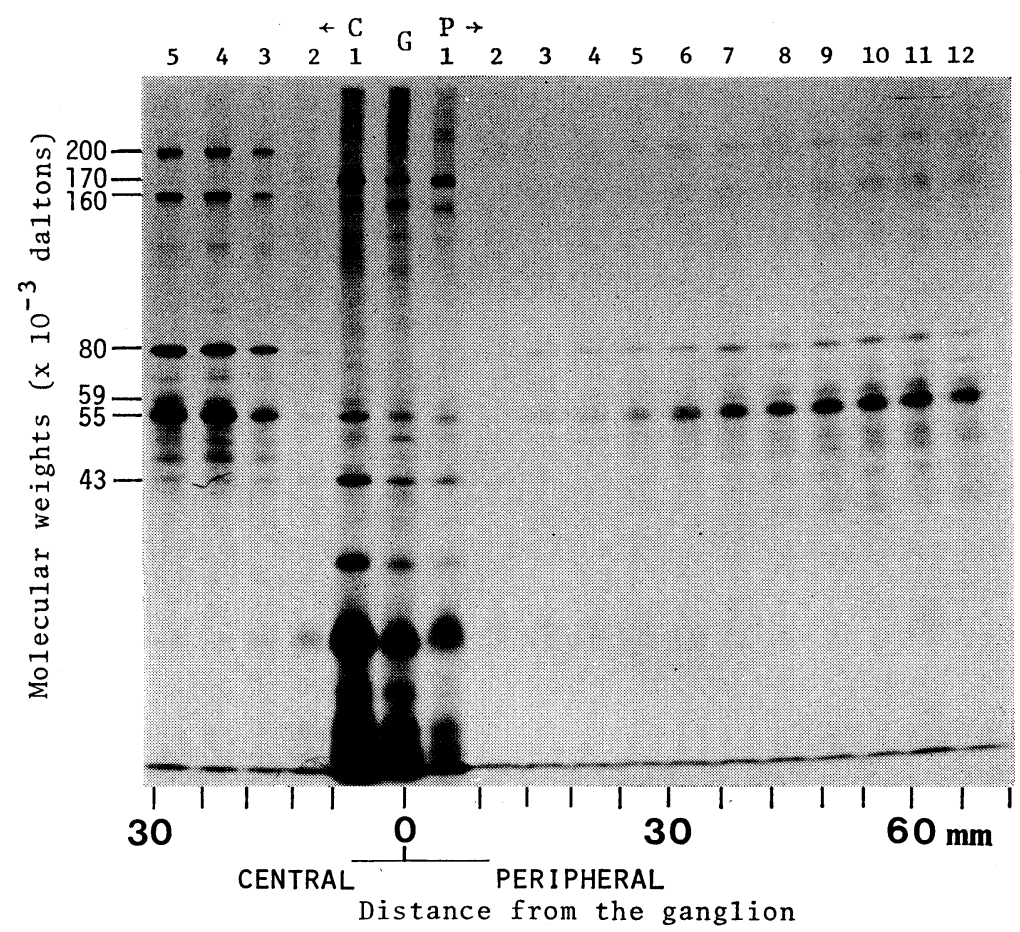

Fig. 3. Fluorograph of axonal peptides 6 weeks after the injection of $\mathrm{L}-\left[{ }^{35} \mathrm{~S}\right]$ methionine into the $\mathrm{L}_{5}$ dorsal root ganglion of the adult rat.

as defined by Lasek and Hoffman, $\left.{ }^{5)}, 8\right)$ which they suggested to be associated with neurofilaments. This group migrates at the slowest rate (Figs. 1, 2 and 3).

Group 2: This consists of two peptides with apparent molecular weights of 59,000 and 55,000 daltons. These peptides have electrophoretic mobilities identical with authentic tubulin preparation ( $\alpha$ and $\beta$ subunits) purified from the porcine brain by two cycles of temperature-dependent depolymerisation-polymerisation and by a subsequent gel filtration. ${ }^{3)}$ Group 2 moves faster than the group 1, but slower than the group 3 (Figs. 1, 2 and 3).

Group 3: This is represented by a 43,000-dalton peptide, of which the electrophoretic mobility is almost identical with that of actin isolated from the rabbit skeletal muscle. This peptide moves most rapidly among the three groups (Figs. 1, 2 and 3).

Each of these three groups moves at a slower rate in the central branch than in the peripheral one, as is most clearly evidenced in Fig. 3. In the central branch, the slow-component triplet and tubulins are clearly seen in the column $\mathrm{C}_{4}$, while almost no radioactivities are detectable in the $\mathrm{P}_{4}$ column. Even in columns $\mathrm{P}_{5}-\mathrm{P}_{12}$, radioactivities 
representing the triplet and tubulins are much less than in the column $\mathrm{C}_{4}$.

At present, we do not know the biological significance of the asymmetric transport between the central and peripheral branches of bifurcating axons. It has been shown that in the mature axons as compared with immature ones, the neurofilament/microtubule ratio as seen by electron microscopy is high, ${ }^{10)}$ and the rate of slow transport is low. ${ }^{4)}$ It has been reported that the density of microtubules as seen by electron microscopy is lower in the central branch than in the peripheral one, while the density of neurofilaments is equivalent between the two branches, ${ }^{11), 12)}$ implying that the neurofilament/microtubule ratio is higher in the central branch. In addition, it is our observation that the rate of slow transport is lower in the central branch than in the peripheral one. ${ }^{6)}$ On the basis of these observations, it is tempting to speculate that the central branch of the DRG cell axons attains maturity at an earlier stage as compared with the peripheral branch.

This work was supported in part by Research Grants 137009, 212004 and 238010 from the Ministry of Education, Japan, and by a Grant from the Mitsubishi Foundation.

\section{References}

1) Abe, T., Haga, T., and Kurokawa, M. (1973) : Biochem. J., 136, 731-740.

2) Bonner, W. M., and Laskey, R. A. (1974) : Eur. J. Biochem., 46, 83-88.

3) Haga, T., and Kurokawa, M. (1975) : Biochem. Biophys. Acta, 392, 335345 .

4) Hendrickson, A. E., and Cowan, W. M. (1971) : Exptl. Neurol., 30, 403-422.

5) Hoffman, P. N., and Lasek, R. J. (1975) : J. Cell Biol., 66, 351-366.

6) Komiya, Y., and Kurokawa, M. (1978): Brain Res., 139, 354-358.

7) Laemmli, U. K. (1970) : Nature, 227, 680-685.

8) Lasek, R. J., and Hoffman, P. N. (1976): Cell Motility (Goldman, R., Pollard, T., and Rosenbaum, J., eds.), pp.1021-1049, Cold Spring Harbor Laboratory.

9) Laskey, R. A., and Mills, A. D. (1975) : Eur. J. Biochem., 56, 335-341.

10) Peters, A., and Vaughn, J. E. (1967) : J. Cell Biol., 32, 113-119.

11) Smith, R. S. (1973) : Can. J. Physiol. Pharmacol., 51, 798-806.

12) Zenker, W., Mayr, R., and Gruber, H. (1975) : Experientia, 31, 318-320. 